\title{
Discussion on Classic Reading Promotion in the University Library in the Internet Plus Era
}

\author{
AN Xiao-li \\ Director of library Chinese journal department, Jiangsu \\ University of Science and Technology \\ Mengxi Road No.2, Zhenjiang City, Jiangsu Province, \\ 212003 \\ E-mail:xiaokedoukedou@126.com
}

\author{
Ding Yi \\ Director of library resource construction department, \\ Jiangsu University of Science and Technology \\ Mengxi Road No.2, Zhenjiang City, Jiangsu Province, \\ 212003 \\ E-mail:dingyehn@163.com
}

\begin{abstract}
Classic reading is a significant component of education. To promote classic reading and improve the quality of education, this study uses approaches of questionnaire to get the status quo of classical reading of college students in the new technology environment, as well as influencing factors. Also, we have obtained a large amount of information about college students reading activities by way of data analysis to carry out precise service. On the Internet plus era, we should establish a reading conception that traditional books reading and digital reading should interact comprehensively. The university library should promote the classical audio books, e-books and online essays as the representative of the digital classic resources. It is important to improve the performance of classical reading service on the Internet plus era, through mining the data on the reading list of individual college students and then carrying out the precise introduction.
\end{abstract}

Keywords—classic; reading promotion; digital reading;e-books; the Internet plus era

\section{INTRODUCTION}

The cultural concern of education is "teaching", by means of "educating people" that cultivate insightful and courageous people, who will be created as a humanistic feelings of intellectuals. In order to shape the self-cultivation and elegant, reading Chinese and foreign classic works plays a crucial role. Reading is part of life-long learning for one's education. Although children are the golden stage of cultivating the interest of reading, but the reading of college students can not be ignored, the formation of the future view of life and the accumulation of future life has an irreplaceable role [1]. Schools, families, university libraries and so on, are important places to carry out reading promotion.

The school library guide (second edition), which published by the International Library Association (IFLA) mentions that the school library has a certain educational activity, and the school librarians should focus on six core teaching activities: cultivation of basic culture literacy and reading promotion; media and information literacy; inquiry learning; technology integration; professional development of teacher; literature and cultural appreciation. In this list, the basic cultural literacy cultivation and reading promotion in the first place, it can be seen that this activity is the basis for other activities.

On the Internet plus era, the reading content and it's carrier has undergone significant changes. Reading short passages or information-based fragmented are increasing, mobile phones and other mobile terminal equipments become the main way for college students to obtain information. More and more experts agree with the digital reading, and digital reading is becoming the mainstream reading way. But in the current, digital reading cannot completely replace the traditional reading, they must complement and mixing development each other [2]. Digital reading is not superficial reading absolutely, and now many paper sales of classic readings have e-book, then it can also be read through mobile phones, computers, readers and other digital devices. The printed material readings are not deep reading necessarily. This paper mainly discusses the propulsion mechanism of classic readings and digital readings on the Internet plus era.

\section{SIGNIFICANT VALUE OF CLASSIC READINGS ON THE INTERNET PLUS ERA}

Classics cover literature, history, philosophy, art, mathematics, economy and so on. This paper focuses on the classic readings of literature and art. From Bacon: " Histories make men wise; poets witty; the mathematics subtitle; natural philosophy deep; moral grave; logic and rhetoric able to contend. Abeunt studia in morse". Huang Tingjian said: "scholar does not read, then loses the justice, looks themselves ugly, and his speech is tasteless". Appreciating classics, the rationalities of readers is formed, their views of world and life will be changed, and their soul will be lifted entirely by classic readings. Although the carrier of the classical literature is changing, the pursuit of the true and the beauty of the Classics will never change. On the Internet plus era, in a fast-paced and high-stress society, people seeking further mental nutrition.

An Xiaoli (1979 - ), female, librarian, master, Jiangsu University of Science and Technology, director of library Chinese journal department. Address: Mengxi Road No.2, Zhenjiang City, Jiangsu Province, Tel 13913443379. E-mail:xiaokedoukedou@126.com。Post code: 212003

Ding Yi: librarian, master, Jiangsu University of Science and Technology director of library resource construction department.

This paper is one of the achievements of the Research on the Application of Precise Marketing Theory in the Disciplinary Service of University Libraries (Project No.: 2017SJB1110) in the Department of Educational and Social Sciences of Jiangsu Province. 


\section{THE CURRENT SITUATION AND INFLUENCING FACTORS OF CLASSIC READING OF COLLEGE STUDENTS ON THE INTERNET PLUS ERA}

\section{A. The survey of students' readers of the Jiangsu University of Science and Technology}

The Jiangsu University of Science and Technology is an engineering-based general institutions of higher learning, the main readers include teachers, graduate students and undergraduates. In view of the object of this study is college students, so we distribute questionnaires to the undergraduate students on-site, after filled out, recovered the questionnaires, provide on-site instructions and $\mathrm{Q} \& \mathrm{~A}$ as well as. The final valid questionnaires are 180 . The questionnaires are about the selection of traditional paper media or digital media, and the choice of literary classics. For example, the fifth question in the questionnaires, "If you read non-professional books which have both e-books and paper books, which one do you prefer?"
In the 180 college students, 28 students choose the e-books (17\%); 86 students choose the paper books (53\%); choose both with 47(30\%); Table 1 expresses the results of the 6 and 8 questions in the questionnaires. From the statistical results, the paper books readers are the mainstream readers, 66 readers use the paper books frequently(41\%); 56 students often read the paper books(35\%); 36 students read occasionally(23\%); two students never read paper books(1\%). Mobile reading is about to catch up with the paper book reading, 44 readers use mobile phones for reading frequently $(27 \%)$; 68 readers often use cell phone $(42 \%)$, the number of mobile readings are more than paper readings. Our university is a shipbuilding specialty, but readers more like literature books than the Traffic Engineering or industrial technology books. In the Table 2, the results of the seventh question, choosing literature books "frequently", "regularly" is far more than other categories. In the "use of the library of those types of document resources ", most of readers use the Chinese paper books, e-book database followed.

TABLE I. ANALYSIS OF QUESTIONNAIRE RESULTS OF COLLEGE STUDENT READERS

\begin{tabular}{|c|c|c|c|c|c|}
\hline \multicolumn{2}{|c|}{ Question } & \multirow{2}{*}{$\begin{array}{c}\text { frequently } \\
66\end{array}$} & \multirow{2}{*}{$\frac{\text { regularly }}{56}$} & \multirow{2}{*}{$\frac{\text { occasionally }}{36}$} & \multirow{2}{*}{$\frac{\text { never }}{2}$} \\
\hline \multirow{4}{*}{$\begin{array}{l}\text { Which carriers do you } \\
\text { use to read generally? }\end{array}$} & P-Book & & & & \\
\hline & $\mathrm{PC}$ & 20 & 38 & 63 & 19 \\
\hline & Cell Phone & 44 & 68 & 37 & 13 \\
\hline & E-reader & 7 & 19 & 57 & 63 \\
\hline \multirow{5}{*}{$\begin{array}{l}\text { Which types of } \\
\text { resources do you often } \\
\text { use in library? }\end{array}$} & Chinese P-books & 64 & 49 & 39 & 7 \\
\hline & $\begin{array}{c}\text { Foreign Language } \\
\text { P-books }\end{array}$ & 7 & 18 & 60 & 53 \\
\hline & $\begin{array}{c}\text { Chinese Paper } \\
\text { Journal }\end{array}$ & 11 & 34 & 47 & 33 \\
\hline & $\begin{array}{c}\text { Foreign Language } \\
\text { Paper Journal }\end{array}$ & 7 & 17 & 41 & 72 \\
\hline & E-books database & 12 & 31 & 49 & 47 \\
\hline
\end{tabular}

\section{B. The current situation of college Students' Classic} Readings on the Internet plus era

(1) Changes in the knowledge carriers: With the development of computer and network technology, and the emergence of a large number of digital media, paper literature gradually developed e-books, electronic journals, electronic newspapers, etc. It needs mobile phones and other digital devices to read. Although the digital media will not completely replace the traditional paper media currently, but the future demands of college students for paper reading are less optimism before the network emergence.

(2) Reading methods change: change from the past pure read into the three ways coexist, ie. reading, listening, watching. Audio books and video resources, enriched the reading way, to realize the diversification of access to knowledge.

(3) In the reading content, current readings transcend the classic readings, utilitarian readings surpass the humanities readings.

(4) On the layers of literature reading, the orientation of shallow readings is obvious. Classic readings are declining, but this does not represent that the classic readings will fade.
C. The influencing factors of college students' classic readings status on the Internet plus era

(1) Digital technology made the changes of the reading media, which is the direct cause of the decline in classic readings. Information transmission technology and Information storage technology cause all reading objects to exist in the form of 0 and 1 , which affects the concentration and depth of reading. It is more suitable for shallow reading with the purpose for leisure and entertainment as well as social intercourse. From printed material reading to the screen reading, daily readings tend to be fragmented, multi-center and impatient without deep experience [3].

(2) As the main body of reading, college students in the study, life and other aspects of the change is the basic reason for the decline in classic readings. The experience of reading the subject in the past is inherited by the excellent classical works. In the present, knowledge is no longer be official or unified, but individual and decentralized, which poses a challenge to the traditional document resources offering and the user services. On the one hand, the classic works are submerged in massive information on the "Internet + era", 
leading college students rare to read the classic; on the other hand, the classic works are obscure, reducing will of reading.

(3) Changes in social and cultural system are the environmental factors of classic reading decline. The moment of quick success, is leading to focus on financial books, civil service exam books and other popular type of books, and people ignore the classic readings. At the same time, the social rhythm is accelerated, the college students lack a kind of peace mind to read the classical literature works.

TABLE II. UNIVERSITY STUDENTS READERS "WHAT KIND OF BOOKS TO READ " QUESTIONNAIRE

\begin{tabular}{|c|c|c|c|c|c|}
\hline \multirow{2}{*}{ CLC Name } & \multirow{2}{*}{$\begin{array}{l}\text { CLC } \\
\text { Ident- } \\
\text { ifiers }\end{array}$} & \multicolumn{4}{|c|}{ undergraduate } \\
\hline & & frequently & regularly & occasionally & never \\
\hline Marxism-Leninist & A & 0 & 7 & 72 & 72 \\
\hline Philosophy & B & 2 & 12 & 81 & 67 \\
\hline $\begin{array}{l}\text { General Social } \\
\text { Sciences }\end{array}$ & $\mathrm{C}$ & 5 & 13 & 81 & 67 \\
\hline Politics \& Law & D & 5 & 10 & 83 & 53 \\
\hline Military & E & 7 & 18 & 83 & 49 \\
\hline Economy & $\mathrm{F}$ & 11 & 34 & 78 & 39 \\
\hline $\begin{array}{c}\text { Culture, } \\
\text { Education, Sports }\end{array}$ & G & 32 & 50 & 66 & 11 \\
\hline Languages & $\mathrm{H}$ & 23 & 59 & 61 & 16 \\
\hline literature & I & 35 & 73 & 47 & 9 \\
\hline Arts & $\mathrm{J}$ & 13 & 32 & 75 & 35 \\
\hline $\begin{array}{l}\text { History, } \\
\text { Geography }\end{array}$ & K & 19 & 45 & 58 & 36 \\
\hline $\begin{array}{l}\text { General Natural } \\
\text { Science }\end{array}$ & $\mathrm{N}$ & 8 & 23 & 72 & 49 \\
\hline $\begin{array}{l}\text { Mathematics and } \\
\text { Chemistry }\end{array}$ & 0 & 19 & 32 & 59 & 50 \\
\hline $\begin{array}{l}\text { Astronomy, Earth } \\
\text { Science }\end{array}$ & $\mathrm{P}$ & 6 & 20 & 64 & 62 \\
\hline Biology & Q & 3 & 8 & 60 & 81 \\
\hline $\begin{array}{l}\text { Medicine \& } \\
\text { Health }\end{array}$ & $\mathrm{R}$ & & & & \\
\hline $\begin{array}{l}\text { Agricultural } \\
\text { Sciences }\end{array}$ & S & 2 & 7 & 47 & 95 \\
\hline Technology & $\mathrm{T}$ & 12 & 30 & 49 & 69 \\
\hline $\begin{array}{l}\text { Transportation } \\
\text { Science }\end{array}$ & U & 8 & 20 & 55 & 72 \\
\hline $\begin{array}{l}\text { Aeronautics and } \\
\text { Astronautics }\end{array}$ & V & & & & \\
\hline $\begin{array}{l}\text { Environment, } \\
\text { Safety Science }\end{array}$ & $\mathrm{X}$ & 6 & 13 & 57 & 76 \\
\hline General Books & Z & 15 & 40 & 60 & 38 \\
\hline
\end{tabular}

IV. PROMOTING COUNTERMEASURES ON COLLEGE STUDENTS' CLASSIC READINGS STATUS ON THE INTERNET PLUS ERA

\section{A. Establishing the perspective of reading that interactive between paper readings and digital readings}

Paper readings and digital readings have their own advantages and disadvantages, so they can be advanced at the same time [4]. The advantages of print resources are easy to save, reading experience comfortable, easy to do pen batch; meanwhile, its' disadvantages include poor interactivity, high cost of replication. On the contrary, digital readings are easy and convenient to retrieve, and have powerful command set; but the credibility of digital resources is not high, the stability is weak, the security of hardware and software are poor. Paper reading and digital reading are not opposed, so college students can freely choose them. They can choose the traditional readings, but also use the Internet to read, even use both of them.

\section{B. Promoting audio classic reading}

In Europe and the United States, as an extension of paper books, audio books reading have been a measurement index of national average per capita amount of reading. There are three benefits of audio-books: the first is it has no bad effect to vision, need not to look at the eyes, just to listen by the ears; the second is there is a wonderful voice involved, more vivid description than just written content, reading more efficient; the third is its' convenient, regardless of walking, shopping or waiting in line waiting for fragmentation time can listen. In China, we recommend two high-quality audio books service platform:

The first is the "365days reading", that started as the form of radio stations, then with the development of information technology, and now you can also use the WeChat public named "365days reading" or Netease cloud music to listen its audio-books. This is a program with a soul, and Updates every day. The program in the famous prose section of the articles have moved, washed away one of our hearts. Each of the exquisite classic prose, coupled with the host of infectious reading, as well as the beautiful melodious music, readings become a deterrent mind of the trip, to help college students, thinking about their future life, seeking truth and goodness.

The second is the "han bai sheng huo" (the public in APP WeChat named: "han bai sheng huo ", or search "reading classic" in podcast). The anchorwomen's pure and emotional sounds attract us deeply. The choice of classic content is also quite ingenuity, such as classic prose, classical poetry, as well as modern prose, classical Chinese literature, modern poetry, foreign poetry. The work collection can make readers comfortable and inspire personality. These audio readings are the new view for promoting college students' classic readings on the Internet plus era.

\section{Precision services for the readers' characteristics on the Internet plus era}

As a leading theory of marketing, the precision marketing theory has been widely used in the business community. Taking the statistical module of the library management system as an example, which includes the readers' borrowing lists, we can select a certain span of time, from January 1, 2017 to May 1, 2017, and the top six college students' borrowing record, then analyze the sample. The first example of student is Zhang HE, who borrowed 46 books, including 37 professional books (software development, AI, data structure, etc.); 5 English books (TOEFL, IELTS, etc.); literary books which include Sherlock Holmes, Lord of the Rings, O. Henry's works. The 
reader is interested in reading detective novels, so we can push other detective novels and O. Henry's masterpiece (such as "The Gift of Magi ", " The Cop and the Anthem ", etc.). The second is Guo JX, a total of 35 books record, the list involves cultural relics, painting, inspirational books, which classic books have "Tactful $\mathrm{Ci}$ " and " Pride and Prejudice". Accordingly, we can push the reading list such as the Song $\mathrm{Ci}$ and Western Classics to the students. The third is graduate student Yang F, a total of 34 books lists, there have not a classic reading in it. The sixth borrowing record has "Alive", "Time for me to tell you(volume one)", " Finding NEMO " etc, so we can push the books list " Time for me to tell you(volume two)" and Yu Hua's other works like " Chronicle of a Blood Merchant "," Brother " to him.

On the other hand, you can also regularly recommend library borrowing list of the Classic to readers, that is, a period of time, top borrow books list. For example, in period of 2017.1.1-2017.5.1 library management system statistics the first 10 kinds of literature books are: "Saw", "Lu Xun Prose Collection", "Wishing you a warm embrace with the world "," IQ84:July - September "," IQ84: 4 Month - June "," moji no satsujin"," Detective's Curse "," The Unbearable Lightness of Being ", "Norwegian Wood"," the White Horse Villa murder"; the top four philosophical books are: "The Republic", " the Interpretation of Dreams", "The Scroll Marked", " Tolerance "; Language class includes: " Walden ", " The little prince ".

\section{The Introduction of Digital Classic Resources on the Internet plus era}

Information on the internet plus era is overload than the lack of knowledge in the past, so the library must shift their work from the construction and protection of resources to the selection and identification of resources. The way of accessing for Digital classic resources includes the following:

\section{1) E-books}

E-books emerge in 2009, according to an US survey, 4/5 of the US publishers are publishing e-books, nearly $9 / 10$ of the US public library provide e-books [5]. Lots of E-book download site provide the resources unevenly. E-books from library and "Baidu reading platform" are reliable.

Library collection of e-books: The advantage is to take a small physical space, the reader easy to access. By using mobile phones and tablet PCs, users can read conveniently; it costs less than paper; it is easy to edit into bibliography and link data deeply, retrieve it quickly. By loading into Repository, it can be conducted to the discovery of knowledge; through network, we use of the e-books from digital library efficiently; Compare the traditional books, e-books reduce the printing and distribution links, then reduce collection time penalty of the traditional books. The disadvantage of e-books is that some of them have restrictions of read, poor reading experience; using it have bad effect to vision; and the category of e-books are far less than print books.

The library community has a unique advantage in the organization, classification, disclosure and description of knowledge resources. With the development of digital technology and the increase of e-books, the advantages of library's description and text mining of e-books are becoming more and more prominent. As one of the lightweight implementations of the semantic web, by extracting the conception of knowledge and establishing model, the Link Data can implement association between the resources, and the internal resources, the e-books and the traditional books. Readers' knowledge discovery is broadened. Therefore, the library' e-books are the key resources of digital classic readings.

Baidu reading website, as one of large number of e-book site, supports for mobile phones, computers, ipad and other ETPIO to read; provides free fragments text, payment for full reading. The price of e-book is lower than the print book [6]. Baidu reading divides all books into 15 categories of books, including the prose essay, Classical Sinology, World Classics and verse, that subordinate to "literary and artistic" are the good choice for students reading digital classic.

\section{2) Network essay}

Short and the time debris reading, the articles need deep thoughts, deeply moved, and excitement. Such as "classic short reading group", the WeChat public from the watercress network, pushes a famous classic short philosophical beauty every day, including three sections: one sentence, a poetry, good morning sentence. Whether it is a word, a passage, or a short essay, will give readers the growth of inspiration and the wisdom of life. This may provoke readers' interest.

\section{CONCLUSION}

The history of human reading reflects the evolution of the text and its carrier, from the hieroglyphs to the alphabets, from such as the bones, the stone, the calf, the cloth to the paper, today to the digital reading carrier, these reflect the great readings of mankind [7]. Digital reading in the future must play an important role. According the history of human reading, digital reading is not the end, but is the current stage of the popular things. All libraries are carrying out digital classic reading and promotional activities, its' effects are different. The evaluation mechanism of digital classic reading promotion deserves to continue to study.

\section{REFERENCES}

[1] XuYan.On the Relationship between "Educated Children"and "Learning Parents".Library Journal, 2017, Issue 06, PP52.

[2] Xu Guiju.Practice and enlightenment on promotion of digital reading service in public library : a case study of Shanghai library. Library, 2017,Issue 4,PP23-24.

[3] Li Xinxiang. A study on the evolution of national reading behavior in digital age.Beijing : China Social Sciences Press,2014,PP374,PP288.

[4] Fang Haiyan.Multiple-dimensional reading : the effective classic reading promotion mode in library. Library Work and Study,2014, Issue 12,PP105.

[5] Molly Raphael. Digital transformation: the impact of e-books and electronic content on readers and libraries. library and information science,2013, Issue 04,PP33.

[6] Baidu reading. Baidu book classification.[online available2017-08-10]. https://yuedu.baidu.com/book/list/7008?show=0.

[7] Wang chengyue,Cao juan.The Review on The Reading Promoter Teaching Materials Series. Library, 2016,Issue 12,PP29. 